\title{
Forskningsnytt
}

Nytt fra internasjonal forskning presentert og kommentert av Anners Lerdal,

redaktør i Sykepleien Forskning og førsteamanuensis ved Høgskolen i Buskerud.

\section{Bedringsprosesser på psykiatrisk institusjon}

Helsearbeideres væremåte bidrar til bedringsprosesser. Dette går frem av en studie som beskriver hva pasienter på en psykiatrisk avdeling opplevde som viktig for egen bedringsprosess.

Undersøkelsen ble gjennomført på en psykiatrisk institusjon for pasienter med planlagte innleggelser. Sykehuset hadde tre døgnavdelinger. Behandlingstilbudet besto av ulike former for psykoterapi, både individuelt og i gruppe.

Artikkelen gir et utfyllende bidrag i forhold til tradisjonell tilnærming hvor pasienter ofte beskrives ut fra etablert kunnskap om diagnoser, tegn og symptomer. Pasientene beskrev atmosfæren og samhandlingen med helsepersonellet på dagvakt som mer terapeutisk og likeverdig enn på seinvakt. Dette er et spennende funn som bør uforskes nærmere.
Data ble samlet inn ved intervju. Et utforskende forskningsopplegg med en fenomenologisk-hermeneutisk tilnærming ble brukt i analyse og tolkning av dataene.

Pasienter ble rekruttert til studien av behandlende lege eller primærsykepleier. Femten pasienter fra de tre avdelingene deltok låtte kvinner og sju menn). Pasientene var innlagt med diagnosene sosial fobi, depresjon, spiseforstyrrelser, posttraumatisk stress eller borderline personlighet. Alderen varierte fra 19-58 år. Intervjuene ble analysert fortløpende. Etter elleve intervjuer erfarte forskerne at de samme temaene gikk igjen.

Analyseprosessen endte i to hovedtema: «helhet og egenverd» og «tid og rom». Det første temaet dreide seg om en opplevelse av at personalet visste hva de gjorde og var i stand til å ta imot følelsesmessige reaksjoner fra pasien- tene. Blant annet skulle personalet finne den riktige balansen mellom å utfordre og gi omsorg. Dette ble uttrykt som: «å ha både hode og hjerte». Én av informantene opplevde at personalet og pasienter «var som en familie». Sammen med trygg atmosfære og vakkert bomiljø. bidro forholdene til en følelse av å være verdifull og normal.

Samværet med andre pasienter og sykepleiere ble også oppfattet som terapeutisk. Atmosfæren i avdelingen fra kl 8 til 16 ble karakterisert ved en «vi-holdning» hvor pasienter og personalet var en helhet. Kveldsvakten bar mer preg av ulikhet mellom pasienter og personalet og en følelse av at personalet var der for å passe på.

\section{REFERANSE}

(Borge L, Fagermoen MS, J Ment Health;2008:17,193-205)

\section{Tidlig utskriving fra sykehus etter hjerteinfarkt}

En relativt høy andel pasienter innlagt med hjerteinfarkt har problemer med å takle stress.

Hensikten med studien var å undersøke mulig samvariasjon mellom opplevelse av sammenheng (OAS), endring i sosial støtte og mestring i forbindelse med innleggelse og utskrivning fra sykehus etter hjerteinfarkt. Begrepet OAS tar utgangspunkt i Antonovskys begrep salutogenese og en hypotese om at menneskets motstandsressurser har betydning for hvordan man takler sykdom og for sykdomsutvikling.

Studien ble gjennomført ved tre sykehus i Sverige. Pasienter som hadde vært innlagt for hjerteinfarkt fylte ut et spørreskjema både like før utskrivning fra sykehus og etter to uker når de var kommet hjem. Spørreskjemaet som målte OAS inneholdt 13 spørsmål hvor respondentene ble bedt om å gradere sine svar på en syvpunkt Likert-skala. Sosialt nettverk og sosial støtte ble målt ved bruk av Social Network and Social Support Scale (SOS-skala), som kartlegger emosjonell støtte, praktisk hjelp, samstemthet og tilgjengelighet.

Av 300 pasienter som ble innlagt på sykehus med symptomer på hjerteinfarkt, deltok 241 i studien. Av disse var 69 prosent menn, 74 prosent var gift og 22 prosent enslige. Sikker hjerteinfarktdiagnose ble stilt hos 208 (86 prosent).

Lave OAS-skårer ble funnet blant 
> TIPS OSS

Kjenner du til nye studier presentert I

internasjonale tidsskrift som du mener har

klinisk relevans og interesse for

norske sykepleiere?

Tips kan sendes til Anners. Lerdalahibu.no

\section{Bidrar resturin til urinveisinfeksjon?}

Resturin hos sykehjemsbeboere bidro ikke til økt forekomst av urinveisinfeksjon (UVI) i løpet av ett års oppfølging.

Dette var et av funnene i en studie som hadde til hensikt å følge opp en kohort av sykehjemsbeboere for å undersøke om det var sammenheng mellom forekomst og mengde av resturin og forekomst av UVI i løpet av det påfølgende året.

Beboere ved seks norske sykehjem ble inkludert i studien i perioden 1999-2002. Informert samtykke ble innhentet, for dem som manglet samtykkekompetanse, undertegnet av et nært familiemedlem. De som var yngre enn 65 år, terminale, brukte urinveiskateter eller ble behandlet med antibiotika da de ble vurdert, ble ikke inkludert. Resturinen til deltakerne ble målt med en ultralydbasert blærescanner ved oppstart av studien. Samtidig ble opplysninger om andre UVI-rela- terte sykdommer kartlagt. I tillegg ble funksjonsnivå vurdert ved hjelp av Barthel Index. Symptomer og tegn på UVI ble registrert i studieperioden.

I alt deltok 153 beboere. Utvalget bestod av 69 prosent kvinner og 31 prosent menn. I løpet av oppfølgingen utviklet 30 prosent en eller flere UVI-er. Kvinner hadde en relativt sett høyere forekomst av UVI enn menn. En multivariant analyse viste at beboere som var kvinner eller hadde urininkontinens, hadde $\emptyset k$ t tendens til få UVI i løpet av oppfølgingsåret. Deltakernes skåre på Barthel Index, forekomst av hjerneslag, Parkinsons sykdom, demens, diabetes, obstipasjon eller resturin ga ikke økt tendens til UVI.

\section{REFERANSE}

IOmli R, Skotnes LH, Mykletun A, Bakke AM, Kuhry E. J Am Geriatr Soc; 2008 : Epub. PMID: 18331294]
Funn i denne studien står i motsetning til hva som trolig er en vanlig oppfatning om at beboere med resturin har $ø k t$ fare for UVI. Det er usikkert i hvilken grad funnene kan generaliseres til andre eldre. Blant annet fordi det ikke oppgis hvem som valgte å ikke delta i studien og hvorvidt denne gruppen eventuelt avvek fra deltakergruppen. Retningslinjene for inklusjon av voksne personer med manglende eller redusert samtykkekompetanse i helsefaglig forskning, utarbeidet av Den nasjonale forskningsetiske komité for medisin i 2005, åpner ikke for at andre kan samtykke for pasienten. Den rådende praksis i Norge er at hvis deltakeren blir vurdert til ikke å ha samtykkekompetanse, blir pårørende spurt og har reservasjonsrett.

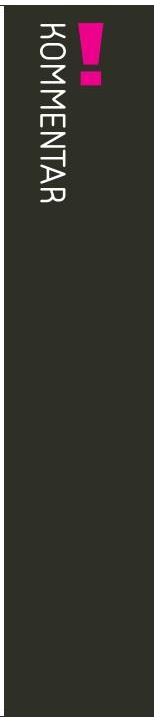

60 prosent av pasientene like etter utskrivning. Det var ingen sammenheng mellom emosjonell støtte og OAS. Etter utskrivning oppga kvinnene, samt menn over 65 år, en reduksjon i sitt sosiale nettverk sammenliknet med to uker tidligere. Menn oppgav en lavere verdimessig samstemthet og tilgjengelighet til nettverket etter at de kom hjem sammenliknet med da de ble innlagt. Studien fant at pasienter som opplevde høy OAS også hadde en tendens til sterkere mestring og at grad av mestring ikke endret seg i løpet av de to ukene.

Ifølge forfatterne viser den høye andelen av pasienter med lav OASskårer at en relativt høy andel pasienter er sårbare. I henhold til Antonovskys teori innebærer lav OAS, det vil si at man har lite ressurser å mobilisere for å håndtere stressende forhold.
Forfatterne gjør et poeng av at en relativt stor andel har lav OAS. Tolkningen av størrelsen på andelen kunne gitt større mening hvis man hadde sammenliknet med en annen gruppe-for eksempel befolkningen generelt. I tabellene er det uklart beskrevet hva som regnes som høy og lav mestring. Dette gjør det vanskelig å tolke tallene som presenteres.

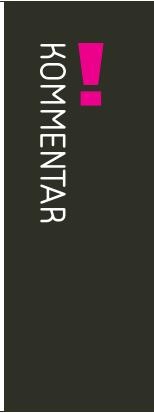

